\title{
Phytochemical Screening and Antibacterial Activity of Hibiscus rosa - sinensis Leaf Extracts
}

\author{
Jyoti V. Vastrad* and Shameembanu A. Byadgi
}

All India Coordinated Research Project on Clothing and Textiles, Main Agriculture Research Station, University of Agricultural Sciences, Dharwad - 580005, Karnataka, India

*Corresponding author

\section{Keywords}

Antibacterial activity,

Escherichia coli, Hibiscus

rosa-sinensis,

Phytochemicals,

Staphylococcus aureus,

Total phenolic content

\section{Article Info}

Accepted:

26 February 2018

Available Online:

10 March 2018

\section{A B S T R A C T}

Plants have been known to be a reservoir of secondary metabolites which are being exploited as source of bioactive substance for various pharmacological purposes. In the present study, fresh leaf extracts of hibiscus were prepared using ethanol, methanol and distilled water. The extracts were assessed for the presence of various classes of phytochemicals by subjecting to different tests and total phenolic content of each extract was carried out using FCR method. Results revealed that all the extracts of hibiscus contained alkaloids, flavonoids and tannins. Saponins and terpenoids were absent in all the leaf extracts of hibiscus. Phenolic concentration of hibiscus was high in ethanol $(425.437 \mathrm{mg} / \mathrm{g})$ than methanol and distilled water extracts. Bioassay results revealed that crude ethanol extract of hibiscus leaves exhibited very good antibacterial activity against $S$. aureus and E. coli compared to $10 \%$ and 5\% extract concentrations. Further, the fabric samples treated with $10 \%$ extract exhibited antibacterial activity only against Staphylococcus aureus. However, antibacterial activity was absent in the samples treated with 5\% hibiscus leaf extract. Thus, the presence of bioactive photochemicals could lend the antibacterial potency to the Hibiscus leaves and therefore, could be utilized not only for their high nutritional values but also as a medical plant.

\section{Introduction}

Plants are a source of great economic value all over the world. Nature has bestowed us with a very rich botanical wealth and a large number of diverse types of plants grown in different parts of the country.

Natural phytochemicals derived from plants have gained significant recognition in the potential management of several human clinical conditions, including cancer (Vastrad et al., 2014). "Phyto" is the Greek word for plant and there are many "families" of phytochemicals that help the human body in a variety of ways. Phytochemicals may protect human being from a host of diseases.

There are non-nutritive plant chemicals that have protective or disease preventive properties. Plant produces these chemicals to protect itself but recent research demonstrates that many phytochemicals can protect humans against diseases (Tiwari et al., 2015). 
Herbal extracts contain different phytochemicals with biological activity that can be of valuable therapeutic index. Different phytochemicals have been found to possess a wide range of activities, which may help in protection against chronic diseases. Phytochemical surveys are being seen as the first step towards the discovery and structural elucidation of useful natural organic constituents for textile or medicinal applications (Hostettmann et al., 2000). The mode of action of plants producing antimicrobial effects on selected textile materials can be better investigated if the active ingredients are identified and characterized (Vastrad et al., 2016).

Flower species have medicinal value and are also well known for possessing various classes of phytoconstituents, a number of which have since found their way into modern medicine. Hibiscus rosa-sinensis belongs to the family of Malvaceae. H. rosa-sinensis is planted as an ornamental plant throughout the tropics and sub-tropics and play a prominent role in human health due to the presence of specific biologically active classes of organic compound (Joshi, 2000). Over 50\% of all modern clinical drugs used today are of natural product origin (Sumathi and Krishinaveni, 2012). In traditional setting, hibiscus has been reported to have been used as anti-asthmatic agent (Ruban and Gajalakshmi, 2012), analgesic, antiinflammatory, antipyretic and possess antitumor properties (Agarwal and Prakash, 2014). Several studies have revealed presence of antimicrobial properties in flowers of Hibiscus rosa-sinensis (Ruban and Gajalakshmi, 2012; Agarwal and Prakash, 2014).

So far there are only a few studies pertaining to phytochemical constituents and pharmacological evaluation of such plants. Hence, the present study was undertaken with an objective to screen the phytochemical constituents present in hibiscus leaves and assess the antimicrobial activity of extracts as well as treated fabrics.

\section{Materials and Methods}

\section{Plant sources and herbal extraction}

Fresh leaves of hibiscus (Hibiscus rosasinensis) were collected from the premises of University of Agricultural Sciences, Dharwad. The leaves were cleaned using distilled water and dried to remove the moisture. $2 \mathrm{~g}$ of fresh leaf was weighed, chopped into fine pieces and ground in a laboratory mortar and pestle. Finely ground leaf was mixed in $25 \mathrm{ml}$ of the solvent $(70 \%$ ethanol, $70 \%$ methanol and distilled water) and incubated for 24 hours at room temperature. The extract was centrifuged at $5000 \mathrm{rpm}$ at room temperature and supernatant was separated. Residue was reextracted with $25 \mathrm{ml}$ of the respective solvent and the process was repeated (Vastrad et al., 2014). The supernatants were pooled and the extract obtained was measured, filtered using Whatman filter paper no. $40(125 \mathrm{~mm})$.

\section{Characterization of leaf extracts}

\section{Phytochemical analysis}

Plants produce different class of secondary metabolites such as alkaloids, tannins, flavonoids, phenols, saponins, glycosides, terpenoids and so on that are responsible for therapeutic and defense properties. The phytochemical screening of plant extracts was carried out according to the standard procedures as mentioned in Table 1 .

\section{Total phenolic content (TPC)}

Total Phenolic Content (TPC) in the extracts was determined according to Folin-Ciocalteu procedure (Singleton and Rossi, 1965) with 
little modification using gallic acid as the reference standard. The total phenolic content was expressed as gallic acid equivalent in milligrams per $1 \mathrm{~g}$ of fresh leaf. Further, completely randomized design was applied to interpret the results.

\section{Bioassay of plant extracts}

Bioassay was carried out to assess the antibacterial activity of the plant extracts by Well Diffusion Method. The bacterial species viz., Staphylococcus aureus (ATCC 6538) and Escherichia coli (ATCC 8739) were used for the study. Nutrient media and nutrient broth was prepared separately in distilled water and autoclaved at $120{ }^{\circ} \mathrm{C}$ for 15 minutes at a pressure of $15 \mathrm{lb}$. A loopful of bacterial ( $S$. aureus and E. coli) cultures was mixed separately in the nutrient broth and kept under shaking condition for 24 hours.

The bacterial inoculum was uniformly spread on sterile Petri plates and allowed to solidify. Later, four wells were created using a cork borer (10 $\mathrm{mm}$ diameter). The ethyl alcohol extract $(100 \%, 10 \% \& 5 \%)$ of selected plant sources were added to each of the respective 3 wells, one well of 70 per cent ethyl alcohol. The Petri plates were incubated for 18-24 hrs and observed for bacterial growth. Zone of inhibition of the bacterial growth was measured in $\mathrm{mm}$.

\section{Application of antimicrobial finish on textiles}

Ethanol extracts $(5 \% \& 10 \%)$ of plant sources were applied on pre-treated cotton fabric by pad-dry-cure method. The fabric was immersed in the plant extract containing 6\% citric acid (binding agent) for ten minutes and passed through pneumatic padding mangle (Plate 1) at a speed of $3 \mathrm{~m} / \mathrm{min}$ with a pressure of $1 \mathrm{~kg} / \mathrm{cm}^{2}$ to remove excess solution. Later, the fabric was air dried and cured for 3 minutes at $140{ }^{\circ} \mathrm{C}$.

\section{Antimicrobial activity of treated fabrics}

The treated fabrics were then tested for antibacterial activity as per AATCC 147 test standard. Sterilized nutrient agar was poured in petri plates and allowed to gel firmly. $1 \pm$ $0.1 \mathrm{ml}$ of 24 hours old broth culture was transferred into $9 \pm 0.1 \mathrm{ml}$ sterile distilled water and mixed properly. One loopful of diluted inoculum was loaded and five lines of $60 \mathrm{~mm}$ length spacing $10 \mathrm{~mm}$ apart were streaked on the solidified agar surface.

Test specimens of size $25 \mathrm{~mm}$ x $50 \mathrm{~mm}$ were pressed transversely across the five streaks to ensure the intimate contact with the agar surface. The plates were incubated at $37 \pm 2$ ${ }^{\circ} \mathrm{C}$ for 18 hours. The incubated plates were examined for interruptions of bacterial growth along the streaks of inoculum, beneath the specimen and beyond the fabric edge (Anonymous, 2013).

\section{Results and Discussion}

\section{Yield of extracts}

Figure 1 depicts the yield of extracts obtained using different solvents. It is observed that yield of hibiscus extract was high with methanol $(40 \mathrm{ml} / 50 \mathrm{ml})$ solvent followed by ethanol $(39 \mathrm{ml} / 50 \mathrm{ml})$ and aqueous $(30 \mathrm{ml} / 50 \mathrm{ml})$ solvents. It was observed that both ethanol and methanol gave best results to extract phenolic compounds because of the presence of polar groups. Moreover, extracting solvent significantly affected the yield of extracts indicating that different extracting solvents influenced different yields of extracts. Further, Dai and Mumper (2010) stated that increase in the extraction temperature can promote higher solubility of insoluble compound present in the leaves. In addition, the surface tension and viscosity of solvent may denature the cell membrane and simultaneously dissolve and stabilize the extracts. 
Table.1 Standard qualitative tests for screening the presence of phytochemicals

\begin{tabular}{|c|c|c|c|}
\hline Phytochemicals & Tests & Reagents & Positive results \\
\hline \multirow[t]{2}{*}{ Alkaloids } & $\begin{array}{l}\text { Dragendorff's } \quad \text { test } \\
\text { (Raaman, 2006) }\end{array}$ & Dragendorff reagent & Prominent yellow ppt \\
\hline & $\begin{array}{l}\text { Wagner's test } \\
\text { (Raaman, 2006) }\end{array}$ & Wagner reagent & Reddish brown ppt \\
\hline \multirow[t]{2}{*}{ Flavonoids } & $\begin{array}{l}\text { Ammonia test } \\
\text { (Rahul et al., 2010) }\end{array}$ & $1 \% \mathrm{NH} 3$ & Yellow colour \\
\hline & $\begin{array}{l}\text { Sodium hydroxide test } \\
\text { (Ajayi et al., 2011) }\end{array}$ & $20 \% \mathrm{NaOH}, \mathrm{HCl}$ & $\begin{array}{l}\text { Yellow colour; on } \\
\text { addition of } \mathrm{HCl} \text { turns } \\
\text { to colourless }\end{array}$ \\
\hline \multirow[t]{3}{*}{ Tannins } & $\begin{array}{l}\text { Ferric chloride test } \\
\text { (Raaman, 2006) }\end{array}$ & $5 \% \mathrm{FeCl} 3$ & $\begin{array}{l}\text { Blue-black or blue- } \\
\text { green colouration }\end{array}$ \\
\hline & $\begin{array}{l}\text { Gelatin test } \\
\text { (Rahul et al., 2010) }\end{array}$ & $\begin{array}{l}1 \% \text { gelatin solution } \\
\text { containing } 10 \% \mathrm{NaCl}\end{array}$ & White ppt \\
\hline & $\begin{array}{l}\text { Lead acetate test } \\
(\text { Raaman, 2006) }\end{array}$ & $10 \%$ lead acetate & Bulky white ppt \\
\hline Saponins & $\begin{array}{l}\text { Foam test } \\
\text { (Ajayi et al., 2011) }\end{array}$ & $\begin{array}{l}20 \mathrm{ml} \text { distilled water } \\
\text { (mixed vigorously for } \\
15 \mathrm{~min} \text { ) }\end{array}$ & Presence of froth \\
\hline Terpenoids & $\begin{array}{l}\text { Salkowski test } \\
\text { (Ajayi et al., 2011) }\end{array}$ & $\begin{array}{l}0.5 \mathrm{ml} \text { chloroform, } 1 \mathrm{ml} \\
\text { conc. } \mathrm{H} 2 \mathrm{SO} 4\end{array}$ & $\begin{array}{l}\text { Reddish brown } \\
\text { colouration at the } \\
\text { interface }\end{array}$ \\
\hline
\end{tabular}

Table.2 Phytochemical screening of hibiscus leaf extracts

\begin{tabular}{|c|c|c|c|c|}
\hline \multirow[t]{2}{*}{ Sl. No. } & \multirow[t]{2}{*}{ Chemical tests } & \multicolumn{3}{|c|}{ Hibiscus } \\
\hline & & Ethanol & Methanol & Aqueous \\
\hline I. & Alkaloids & & & \\
\hline 1. & Dragendorff's test & - & + & + \\
\hline 2. & Wagner's test & + & + & + \\
\hline II. & Flavonoids & & & \\
\hline 1. & Ammonia test & + & + & + \\
\hline 2. & Sodium hydroxide test & + & + & + \\
\hline III. & Tannins & & & \\
\hline 1. & Ferric chloride test & + & + & - \\
\hline 2. & Gelatin test & + & + & + \\
\hline 3. & Lead acetate test & + & + & + \\
\hline IV. & Saponins & & & \\
\hline 1. & Foam test & - & - & - \\
\hline V. & Terpenoids & & & \\
\hline 1. & Salkowski test & - & - & - \\
\hline
\end{tabular}
$(+)=$ present
$(-)=$ absent 
Table.3 Total phenolic content of the extracts

\begin{tabular}{|c|c|c|c|c|c|c|}
\hline & \multicolumn{2}{|c|}{ Aqueous } & \multicolumn{2}{|c|}{ Ethanol } & \multicolumn{2}{|c|}{ Methanol } \\
\hline & $\mu \mathrm{g} / \mathrm{ml}$ & $\begin{array}{l}\mathrm{mg} / \mathrm{g} \text { of } \\
\text { fresh leaf }\end{array}$ & $\mu \mathrm{g} / \mathrm{ml}$ & $\begin{array}{l}\mathrm{mg} / \mathrm{g} \text { of } \\
\text { fresh leaf }\end{array}$ & $\mu \mathrm{g} / \mathrm{ml}$ & $\begin{array}{l}\mathrm{mg} / \mathrm{g} \text { of } \\
\text { fresh leaf }\end{array}$ \\
\hline TPC & 1784 & 26.653 & 21850 & 425.437 & 16272 & 319.686 \\
\hline SD & \multicolumn{2}{|c|}{0.836} & \multicolumn{2}{|c|}{10.139} & \multicolumn{2}{|c|}{13.118} \\
\hline CV (\%) & \multicolumn{2}{|c|}{3.136} & \multicolumn{2}{|c|}{2.383} & \multicolumn{2}{|c|}{4.103} \\
\hline CD (1\%) & \multicolumn{6}{|c|}{$12.705 * *$} \\
\hline
\end{tabular}

**Highly significant @ 1\% level of significance

Table.4 Antibacterial activity of hibiscus leaf extract by Well diffusion method

\begin{tabular}{|c|c|c|c|c|}
\hline \multirow{2}{*}{$\begin{array}{c}\text { S. } \\
\text { No. }\end{array}$} & Details & Concn. & \multicolumn{2}{|c|}{ Zone of inhibition (mm) } \\
\hline $\mathbf{1}$ & Control (70\% ethanol) & - & Staphylococcus aureus & Escherchia Coli \\
\hline 2 & Hibiscus leaf extract & 100 & 09 & 08 \\
\hline & 10 & 15 & 15 \\
\hline & & 5 & No zone & 10 \\
\hline
\end{tabular}

Table.5 Antibacterial activity of fabric treated with hibiscus leaf extract

\begin{tabular}{|c|c|c|c|c|c|}
\hline \multirow{2}{*}{$\begin{array}{l}\text { Sl. } \\
\text { No. }\end{array}$} & \multirow[t]{2}{*}{ Details } & \multirow{2}{*}{$\begin{array}{l}\text { Concn. } \\
(\%)\end{array}$} & \multicolumn{2}{|c|}{ Zone of inhibition } & \multirow[t]{2}{*}{ Inference } \\
\hline & & & Staphylococcus aureus & Escherchia Coli & \\
\hline 1 & $\begin{array}{l}\text { Control } \\
\text { (untreated) }\end{array}$ & - & $\begin{array}{l}\text { Growth under and } \\
\text { above the specimen }\end{array}$ & $\begin{array}{l}\text { Growth under and } \\
\text { above the specimen }\end{array}$ & $\begin{array}{c}\text { Antibacterial activity } \\
\text { absent }\end{array}$ \\
\hline \multirow[t]{2}{*}{2} & \multirow{2}{*}{$\begin{array}{l}\text { Fabric treated } \\
\text { with hibiscus } \\
\text { leaf extract }\end{array}$} & 5 & $\begin{array}{l}\text { No zone, growth under } \\
\text { the specimen }\end{array}$ & $\begin{array}{l}\text { No zone, growth } \\
\text { under the specimen }\end{array}$ & $\begin{array}{l}\text { Antibacterial activity } \\
\text { absent }\end{array}$ \\
\hline & & 10 & No zone, no growth & $\begin{array}{l}\text { No zone, growth } \\
\text { under the specimen }\end{array}$ & $\begin{array}{l}\text { Antibacterial activity } \\
\text { present only against } \\
\text { Gram positive bacteria }\end{array}$ \\
\hline
\end{tabular}

Plate.1 Application of hibiscus leaf extracts on cotton fabric by pad-dry-cure method
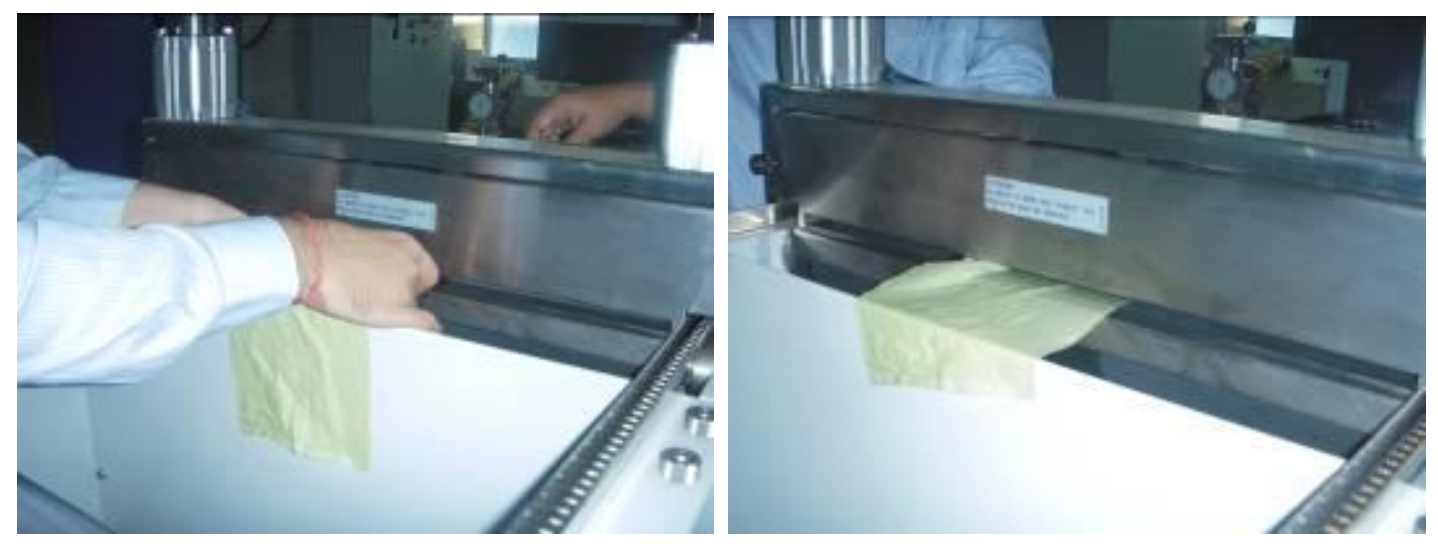
Plate.2 Antibacterial activity of hibiscus leaf extracts: Staphylococcus aureus (A) \& Escherichia coli (B)
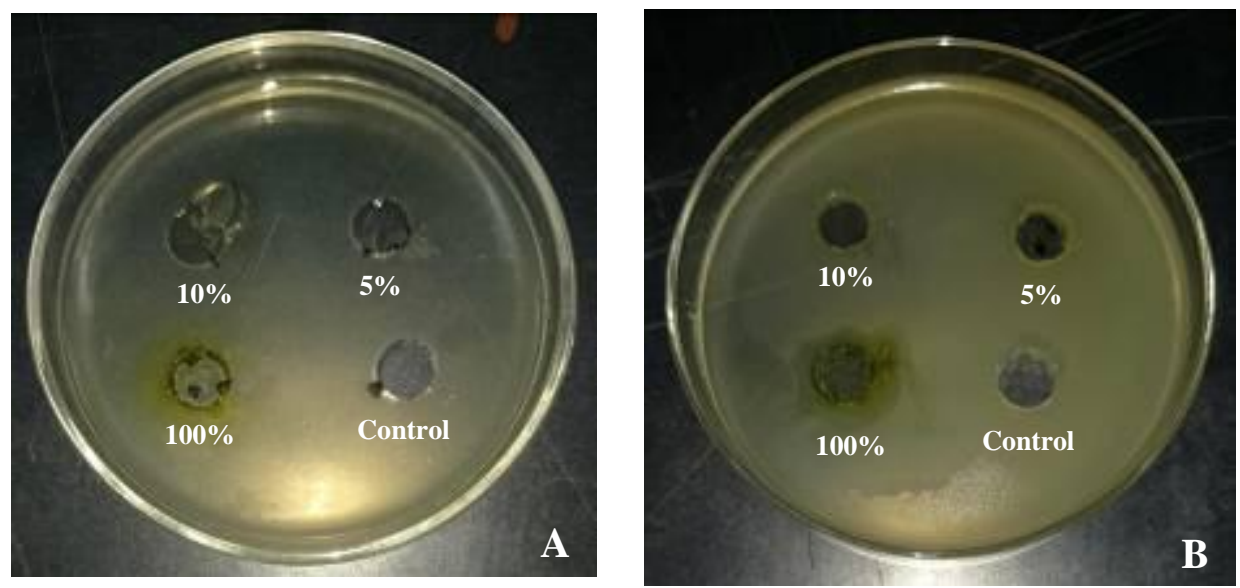

Plate.3 Antibacterial activity of cotton fabric treated with hibiscus leaf extracts: Staphylococcus aureus (A) and Escherichia coli (B)
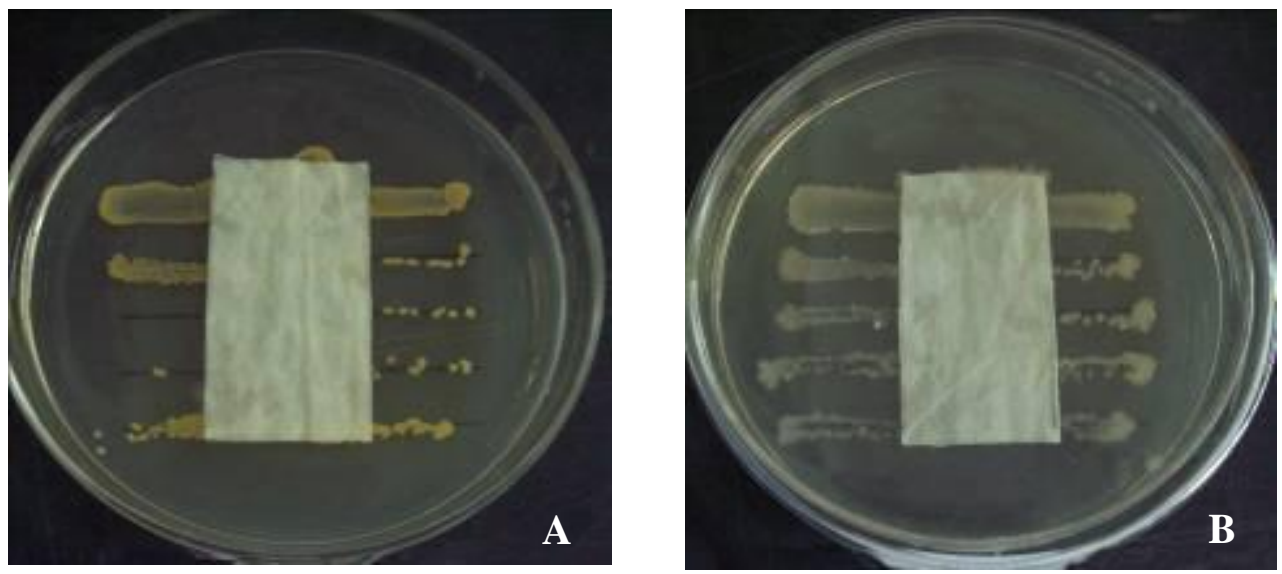

Fig.1 Yield of hibiscus leaf extracts (ml/ 50ml)

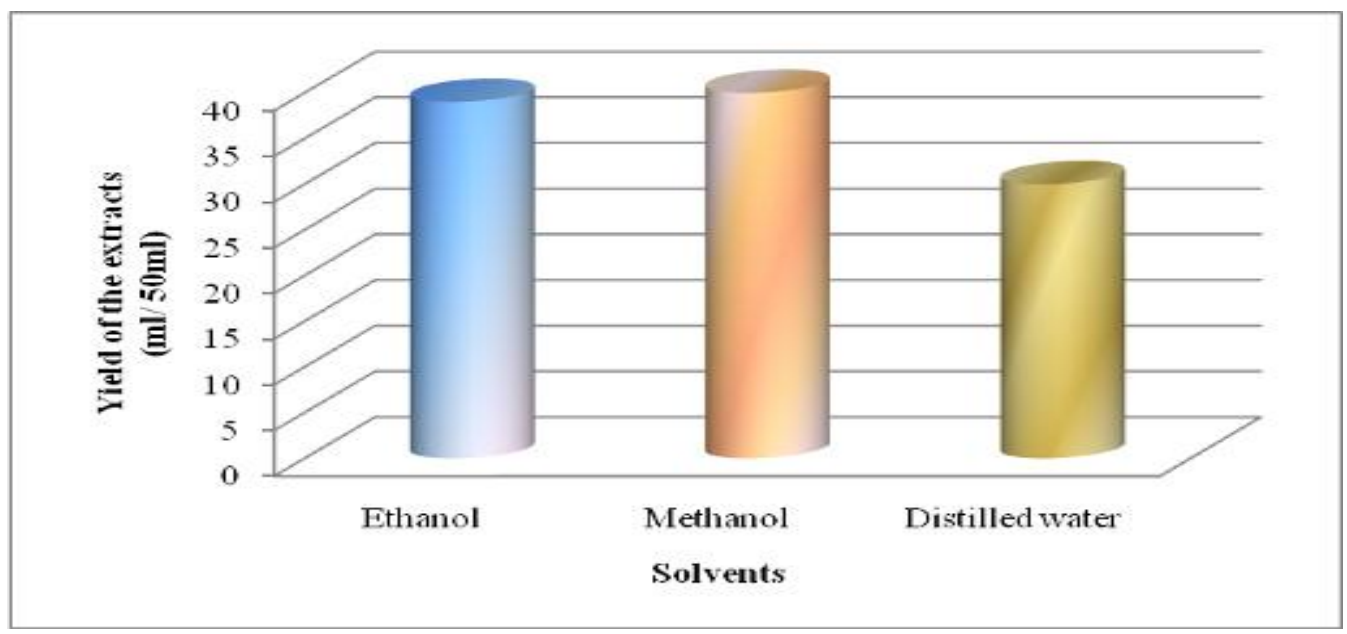




\section{Characterization of leaf extracts}

\section{Phytochemical screening}

The phytochemical screening of hibiscus extracts using ethanol, methanol and distilled water is recorded in Table 2.

It is evident from the Table that the presence of alkaloids was positively proved by both the tests i.e. Dragendorff's and Wagner's test in all the extracts of hibiscus, except for ethanol extract of hibiscus which depicted negative results with Dragendorff's test. Alkaloids exhibit marked physiological effects; hence their wide use in medicines for development of drugs is gaining high demand. They produce pain-relieving and bactericidal effects.

Flavonoids were detected to be present in ethanol, methanol and distilled water extracts of hibiscus using both ammonia and sodium hydroxide tests. Presence of tannins determined by gelatin and lead acetate tests exhibited significantly positive results in all the extracts of hibiscus whereas ferric chloride test did not prove the presence of tannins in distilled water extract. Flavonoids and tannins are phenolic compounds that are a major group of compounds acting as primary antioxidants.

None of the extracts of hibiscus exhibited presence of saponins and terpenoids using foam and Salkowski test, respectively. Terpenoids and saponins showed painrelieving properties as well as central nervous system activities.

The results are in line with Tiwari et al., (2015) and Udo et al., (2016) who reported that bioactive chemical compounds from the phytochemical screening of $H$. rosa-sinensis leaf extracts include alkaloids, tannins, saponins, flavonoids, glycosides, anthraquinones and phenols. The leaf extracts are high enough in essential nutrients required for optimal physiological performance and the maintenance of good health.

\section{Total phenolic content}

Folin-Ciocalteu reagent, a mixture of phosphotungstic (H3 PW12O40) and phosphomolybdic (H3 PMo12O40) acids, is reduced to blue oxides of tungstene (W8 O23) and molybdene (Mo8 O23) during phenol oxidation. This reaction occurs under alkaline condition provided by sodium carbonate. The intensity of blue colour reflects the quantity of phenolic compounds, which can be measured using spectrophotometer.

The phenolic concentration of hibiscus is presented in Table 3. Phenolic concentration of hibiscus was found to be high in ethanol $(425.437 \mathrm{mg} / \mathrm{g}$ of fresh leaf) solvent as compared to methanol $(319.686 \mathrm{mg} / \mathrm{g})$ and aqueous $(26.653 \mathrm{mg} / \mathrm{g})$ solutions. Though, ethanol and methanol gave similar results with respect to total phenolic content, ethanol was selected for further experiment because ethanol is more polar than methanol and also due to the cytotoxic nature of methanol, it is not preferred in textile wet processing.

\section{Bioassay of leaf extracts}

The antibacterial activity of hibiscus leaf extracts against Staphylococcus aureus (Gram positive) and Escherichia coli (Gram negative) was assessed according to Well diffusion test. It is observed from Table 4 (Plate 2) that, the crude extract $(100 \%)$ of hibiscus leaves exhibited very good antibacterial activity against both the test organisms with a zone of inhibition of $15 \mathrm{~mm}$ compared to control. Further, it was observed that, $10 \%$ hibiscus leaf extract showed good antibacterial activity against $S$. aureus $(11 \mathrm{~mm})$ and E. coli $(10 \mathrm{~mm})$. However, no 
zone of inhibition was observed for $5 \%$ hibiscus leaf extract indicating absence of antibacterial activity. The results are in line with the study conducted by Kumari et al., (2015) and Udo et al., (2016).

The variation in the antimicrobial activity of the plant extracts can be attributed to inoculum size, type of media used, type of solvent used for extraction, extraction procedure, incubation time and temperature, part of the plant used and its time of collection, method of extraction procedure, incubation time and temperature, method of antimicrobial assay and strain activity (Jahan et al., 2011).

\section{Antibacterial effect of fabric treated with hibiscus leaf extract}

Antibacterial activity of fabric samples treated with 5 and 10 per cent plant extracts against Staphylococcus aureus and Escherchia coli is depicted in Table 5 (Plate 3). It is apparent from the Table that the antibacterial activity was absent in control (untreated) sample as evident by the growth under and above the specimen.

On the other hand, fabric samples treated with 10 per cent extract showed antibacterial activity only against Gram positive bacteria i.e., Staphylococcus aureus. However, no antibacterial activity was observed among the fabric samples treated with 5 per cent hibiscus leaf extract.

In general, the bigger the zone, the higher is the antibacterial activity but the lack of zone of inhibition does not necessarily mean an absence of activity. A zone is generally shown by antimicrobial agents that are 'leaching type', i.e., they leach out of the fabric and kill the microbes present on as well as around the treated fabric (Kumari et al., 2015).
The various phytochemical compounds detected from hibiscus are known to have beneficial importance in medicinal sciences. Results revealed the presence of alkaloids, flavonoids and tannins in various extracts of hibiscus. However, the phenolic content of hibiscus was high in ethanol solvent. The crude ethanol extract of hibiscus leaves showed very good antibacterial activity against the bacterial species. Since, hibiscus plant is commonly grown in the country; it can serve as cheap source of effective antibacterial agent. However, more advanced studies are needed in order to identify the bioactive principles present in herbs and shrubs suitable for textile wet processing. Moreover, there are innumerable potentially useful plants and herbs that need to be evaluated and exploited for their effective therapeutic application.

\section{References}

Agarwal, S. and Prakash, R. 2014. Evaluation of antibacterial activity of Hibiscus rosa-sinensis flower extract against $E$. coli and B. subtilis. Biological Forum. 6(2):194-196.

Ajayi, I. A., Ajibade, O. and Oderinde, R. A. 2011. Preliminary phytochemical analysis of some plant seeds. Res. J. Chem. Sci. 1: 58 - 62 .

Anonymous, 2013. Training program for testing antimicrobial textiles. The Synthetic and Art Silk Mills' Research Association (Sasmira).

Dai, J. and Mumper, I. J. 2010. Plant phenolics: Extraction, analysis and their antioxidant and anticancer properties. Molecules. pp. 7313-7352.

Hostettmann, K., Marston, A., Ndjoko, K. and Wolfender, Jean-Luc. 2000. The potential of African plants as a source of drugs. Curr. Org. Chem. 4(10): 9731010. 
Jahan, F., Lawrence, R., Kumar, V., Junaid, M. 2011. Evaluation of antimicrobial activity of plant extracts on antibiotic susceptible and resistant Staphylococcus aureus strains. J. Chem. Pharm. Res. 3(4):777-789.

Joshi, S. G., 2000 Medicinal plants. Oxford and IBH Publishing Co. Private Limited, New Delhi: 315.

Kumari, O. S., Baburao, N. and Reddy, K. V. 2015. Phyto-chemical analysis and antimicrobial activity of Hibiscus rosasinensis. World Journal of Pharmacy and Pharmaceutical Sciences. 4(5): 766771.

Raaman, N., 2006, Phytochemical techniques. New India Publishing Agency, New Delhi: 19, 21, 22.

Rahul, C., Pankaj, P., Sarwan, S. K. and Mahesh, J. K. 2010. Phytochemical screening and antimicrobial activity of Albizzia lebbeck. J. Chem. Pharm. Res. 2: 476 - 484.

Ruban, P. and Gajalakshmi, A. 2012. In vitro antibacterial activity of Hibiscus flower against human pathogens. Asian Pac. Journal of Tropical Biomedicine. 2(5): 399-403.

Singleton, V. L. and Rossi, J. A. 1965. Colorimetry of total phenolics with phosphomolybdic-phosphotungstic acid reagents. American Journal of Enology Viticuture. 16: 144-158.

Sumathi, S. and Krishnaveni, M. 2012. Preliminary screening, antioxidant and antimicrobial potential of Chaetomorpha antennina and Caulerapa scalpelliformis invitro study. Int. J. Env. Sci. 2 (3): 10-14.

Tiwari, U., Yadav, P. and Nigam, D. 2015. Study on phytochemical screening and antibacterial potential of methanolic flower and leaf extracts of Hibiscus rosa sinensis. International Journal of Innovative and Applied Research. 3(6): 9- 14.

Udo, I. J., Ben, M. G., Etuk, C. U. and Tiomthy, A. I. 2016. Phytochemical, proximate and antibacterial properties of Hibiscus rosa-sinensis L. leaf. Journal of Medicinal Plants Studies. 4(5): 193-195.

Vastrad, J. V., Byadgi, S. A., Goudar, G. and Kotur, R. 2014. Characterization of phytoconstituents in leaf extracts of forest species for textile applications. Forest Products Journal. 64 (7/8): 259264.

Vastrad, J. V., Goudar, G. and Byadgi, S. A. 2016. Characterization of phenolic compounds in Eucalyptus globulus and Cymbopogan citratus leaf extracts. The Bioscan. 11(4): 2153-2156.

\section{How to cite this article:}

Jyoti V. Vastrad and Shameembanu A. Byadgi. 2018. Phytochemical Screening and Antibacterial Activity of Hibiscus rosa - sinensis Leaf Extracts. Int.J.Curr.Microbiol.App.Sci. 7(03): 3329-3337. doi: https://doi.org/10.20546/ijcmas.2018.703.384 